UDC 541.11

O. Brunetkin, DSc, Assoc. Prof., M. Maksymov

Odessa National Polytechnic University, 1 Shevchenko Ave., Odessa, Ukraine, 65044; e-mail: brunetkin@opu.ua

\title{
DEVELOPMENT OF A MODEL OF PROCESSES FOR THE THER-MAL PROCESSING OF ORGANIC MATTERS OF VARIABLE COMPOSITION
}

\begin{abstract}
О.І. Брунеткін, М.М. Максимов. Розробка моделі процесів термічної переробки органічних речовин змінного складу Метою $є$ розробка єдиної моделі різних процесів термічної переробки органічних речовин. Враховано можливість визначення складу речовин в процесі їх переробки в режимі реального часу. Передбачена можливість обліку різного фазового стану вихідної сировини. Модель будується на основі методу розрахунку процесів горіння палива в рідинних ракетних двигунах. У виконаних раніше роботах проведено порівняння отриманих на ії основі результатів розрахунків з наявними даними для випадку спалювання в повітрі метану і етилового спирту. Запропонована модель відрізняється можливістю обліку в складі продуктів реакції в конденсованої фазі у вигляді вуглистого залишку. Його наявність супроводжує процесу піролізу. Виконано розрахунок складу продуктів процесу повільного піролізу деревини сосни. Проведено порівняння отриманих результатів 3 наявними даними. Для визначення невідомого складу вихідної сировини використовується розроблена раніше модель для випадку газоподібного його уявлення. В результаті визначається брутто-формула газоподібного палива. Особливістю даного процесу $є$ необхідність забезпечення ізоентальпійності процесу горіння. Така умова може бути забезпечено в камері згоряння ракетного типу 3 регенеративним охолодженням. Відзначено, що отримані таким чином результати можуть бути розширені на випадок різних видів горючих речовин в конденсованому стані. Розроблена модель термічного перетворення і на ії основі спосіб визначення невідомого складу гетерофазних органічних горючих речовин може бути використаний при переробці різних альтернативних видів горючих, виробничих і побутових відходів. Визначення в режимі реального часу їх змінного складу може дозволити організацію керованого процесу їх спалювання. В результаті виконаної роботи: обрана і адаптована єдина модель для вирішення завдань спалювання газифікації та повільного піролізу при відомому складі вихідних вуглеводневих речовин; наведені результати розрахунків на їі основі; запропонований метод визначення в режимі реального часу складу вуглеводневої складової горючих речовин в різних агрегатних станах.

Ключові слова: органічна сировина, термічне перетворення, визначення складу
\end{abstract}

O. Brunetkin, M. Maksymov. Development of a model of processes for the thermal processing of organic substances of variable composition. The aim is development of a single model of various processes for the thermal processing of organic substances. The possibility of determining the composition of substances in the process of their processing in real time is taken into account. It is possible to possibility of determining the composition of substances in the process of their processing in real time is taken into account. It is possible to
take into account the different phase state of the feedstock. The model is based on the method of calculating the processes of fuel combustion in liquid rocket engines. In the earlier studies, a comparison was made of the results of calculations based on it with the available data for the case of methane and ethyl alcohol burning in air. The proposed model is distinguished by the possibility of taking into account the composition of the reaction products in the condensed phase in the form of a carbonaceous residue. Its presence accompanies the pyrolysis process. The composition of the products of the process of slow pyrolysis of pine wood is calculated. The results are compared with the available data. To determine the unknown composition of the feedstock, the previously developed model for the case of gaseous presentation is used. As a result, the gross formula of the gaseous fuel is determined. The peculiarity of the process under consideration is the need to ensure isoenthalpy of the combustion process. Such a condition can be provided in a rocket type combustion chamber with regenerative cooling. It is noted that the results obtained in this way can be extended to the case of various types of combustible substances in a condensed state. The developed model of thermal conversion and, on its basis, a method for determining the unknown composition of heterophasic organic combustible substances can be used in the processing of various alternative types of combustible, industrial, and household waste. The real-time determination of their variable composition may allow the organization of a controlled process of burning them. As a result of the work: a single model is selected and adapted to solve the problems of combustion, gasification and slow pyrolysis with a known composition of the initial hydrocarbon substances; results of calculations based on it are given; A method for determining the real-time composition of the hydrocarbon component of combustible substances in various states of aggregation is proposed.

Keywords: organic raw materials, thermal conversion, composition determination

\section{Introduction}

One of the cornerstones in ensuring the efficient operation of jet engines, gas turbines is the ability to implement a controlled, controlled process of burning fuel, usually organic. It is possible to assume that issues related to the burning of organic substances are most deeply worked out precisely in 
jet engine building. This applies both to their scientific side and to their practical implementation. There are other areas of technology where the issues of thermal processing of organic substances and, in particular, their combustion play an important, or even decisive, role. These include the use of gases after oil and coke processing, blast furnace gases, fermentation gases in digesters, etc. Separately, it is possible to single out the issues of thermal processing of raw materials in the wood-chemical industry. This list should include the tasks of processing various wastes, primarily household waste, using pyrolysis or incineration. The list goes on.

As part of the thermal processing of organic substances, various directions can be distinguished, in particular, combustion, gasification, and slow pyrolysis. At the moment, with the similarity of the chemistry of the reactions in the indicated directions, different models are used to study the ongoing processes. In this case, only the known composition of the feedstock is considered. This makes it difficult to apply the obtained results in practice. In a real situation, the composition of the raw material is not only unknown, but also variable in time. In this regard, it seems relevant to develop a single model for the indicated areas with the ability to determine the composition of the feedstock in real time. Such a model can be built on the basis of the most developed theory of fuel combustion used in jet engines.

In modern technology there is a look at its interaction with various fields of applied science. A common point of view is a certain orientation of relations: the results of scientific research serve the process of developing technical objects. Moreover, the needs of developers can stimulate new research. The construction of a unified model for studying the issues of thermal processing of organic substances based on the theory of combustion developed in another field of technology can allow the use of technical solutions from this area for the implementation of the processes under study. In other words, in this case, in contrast to the widespread one, another direction of interaction between the results of scientific research and their technical implementation can be realized: based on the existing technical developments in jet engine building, a model for the thermal processing of organic raw materials is constructed.

\section{Literature review and problem statement}

Volumes of consumption and the cost of extracted organic energy resources are growing, and explored reserves are decreasing. This is one of the reasons for the increased interest in alternative sources. Potentially, the volumes of such resources are large. So only the amount of associated gas from oil production, neutralized by burning in flare devices, according to the World Bank [1] in 2017 amounted to 141 billion cubic meters. In [2] it is noted that its rational use would provide electricity for the African continent during the year. On the other hand, the cost of this gas may be about 30 billion USD, which corresponds to a quarter of gas consumption in the United States or 30\% in the European Union annually. In addition to the energy component, environmental issues also find their place in the spectrum of interests in the processing of associated gases and various types of waste. According to the United Nations Intergovernmental Panel on Climate Change (IPCC) [3], the greenhouse activity of methane per 100 years is 28 times stronger than that of carbon dioxide of the same volume generated during methane burning. In a 20-year perspective, this value is even greater -84 times. It is necessary to add to associated gases difficult to estimate, but significant volumes of gases in the form of industrial waste, thermal processing of agricultural waste, wood chemical, pulp and paper and other industries, household waste processing. For the most part, they also consist of methane.

The main process in obtaining energy from organic raw materials is its burning. Other processes may also serve as intermediate. These are gasification and pyrolysis. And already their reaction products are again burned. Historically, the study of issues related to the study of combustion, gasification, and pyrolysis began at various points in time and was carried out by various research groups. In each case, various substances acted as the starting materials and various search goals were set. So when burning, the possibility of maximum heat generation by eliminating underburning or excess air is sought. In contrast, during gasification, the goal is reducing energy losses as a result of the reaction while simultaneously producing a mixture of combustible gases with the highest possible calorific value. In the process of pyrolysis, in contrast to the two previous cases, the supply of energy in the form of heat is required. Carbon residues, condensing substances and non-condensing gases act as 
products of the process. Search in each area is based on differing approaches and models. From such positions, the latest review [4] reflects the contribution of a leading group of European and American researchers in the various areas. But in the same work, this approach conflicts with the unified classification of processes and starting materials in their research as "thermochemical processing of biomass". The search for alternative energy sources and, at the same time, the possibility of processing waste is of interest to scientists around the world [5]. Relevant reviews of previous years [6-7] indicate many years of interest in this issue.

In a number of works, the possibility of a smooth transition of one process to another or the implementation of various processes, or even their joint course on the same equipment, is noted. So in [8] an attempt is made to consider the gasification process as a special case of the combustion process. This implies the possibility of applying in both cases a single model for describing various processes of thermal processing of biomass. It is only necessary to vary the coefficient of excess oxidizing agent. This requires the study of these related processes with various combinations of parameters $[9-11]$. In [12], a variant of the operation of pyrolysis plants in the presence of a small amount of air is considered. This process is called "quasi-pyrolysis". On the same equipment, using identical raw materials, various processes can be implemented. In this case, a conflict appears between the applied pyrolysis and gasification models. It becomes difficult to resolve with uncontrolled changes in the composition of the feedstock or the amount of air (suction). There are many other factors that influence the pyrolysis process. They are all analyzed individually or in some groups [13-15]. Substances of different initial composition, various equipment configurations, process parameters, etc. are considered.

A unifying feature of most works is the consideration of various, but necessarily known starting materials as initial materials. In contrast, in a real situation, the case of unpredictable changes in the processing of the composition of the raw material is practically important. It seems important to develop a method for determining the variable composition used for the processing of starting materials in real time. In [16], a model is proposed, and in [17] based on it, such a method is developed, but only for the case of gaseous substances. The extension of this method to the case of using starting materials in other phase states within the framework of a single model for describing the processes of combustion, gasification, and slow pyrolysis is relevant.

\section{The aim and objectives of research}

The aim of research is development of a unified method for identifying the combustion, gasification and slow pyrolysis of hydrocarbons of unknown and variable composition. This will allow the rational use of hydrocarbon substances from a technological, energy and environmental perspective.

To achieve the aim, the following objectives are set:

- to select and adapt for the calculation of the processes under consideration a single model for solving the problems of combustion, gasification and slow pyrolysis with a known composition of the initial hydrocarbon substances;

- to determine the magnitude of the error introduced by various perturbations in the solution of the corresponding problems;

- to develop, within the framework of the chosen model, a method for determining in real time the composition of the initial hydrocarbon substance in various states of aggregation.

Method for solving the problems of combustion, gasification and slow pyrolysis of hydrocarbon substances of unknown and variable composition

\section{The choice and adaptation of a single solution method}

One of the features of the processes under consideration is the gaseous state of their products. In addition, with all the variety of hydrocarbon substances, the number of chemical elements that make up their composition is limited. Most often it is carbon $(\mathrm{C})$, hydrogen $(\mathrm{H})$, oxygen $(\mathrm{O})$ and nitrogen $(\mathrm{N})$. Less often sulfur $(\mathrm{S})$ and phosphorus $(\mathrm{P})$. Due to this, the amount of generated gases is also limited, which greatly facilitates the solution of the problem.

For definiteness, let's consider the starting material, which consists of only three elements: (C), $(\mathrm{H})$, and $(\mathrm{O})$ ). This does not fundamentally change the nature of the solution, but significantly reduces 
the bulkiness of the calculations. Using the selected elements, the following can be described as starting products:

- gaseous - saturated and unsaturated hydrocarbons, etc.;

- liquid - alcohols, aldehydes, organic acids, phenols, etc.;

- solid - wood, agricultural waste (cellulose, lignin), plastic waste, etc.

For pyrolysis, it does not matter which of the above elements are part of the starting material. In developing calculation methods for combustion and gasification, air can be used as an oxidizing agent. Nitrogen in the air does not change the essence of the processes and acts mainly as ballast. The amount of nitrogen oxides formed is not large and does not fundamentally affect the ongoing processes. The presence of nitrogen in the air requires consideration of an additional chemical element $(\mathrm{N})$.

In the calculation results, the following gases and the elements of which they consist can act as products:

$$
\text { [CO], [CO } \left.\mathrm{CO}_{2}\right],\left[\mathrm{H}_{2} \mathrm{O}\right],[\mathrm{OH}],[\mathrm{NO}],\left[\mathrm{H}_{2}\right],\left[\mathrm{O}_{2}\right],\left[\mathrm{N}_{2}\right],[\mathrm{H}],[\mathrm{O}],[\mathrm{C}],[\mathrm{N}] \text {. }
$$

Based on similar initial data and assumptions, a model is proposed in [6] for determining the unknown composition of gaseous fuel in the form of its gross formula, presented in the form:

$$
\mathrm{C}_{b \mathrm{C}} \mathrm{H}_{b \mathrm{H}} \mathrm{O}_{b \mathrm{O}} \mathrm{N}_{b \mathrm{~N}} \text {. }
$$

Here $b \mathrm{C}, b \mathrm{H}, b \mathrm{O}, b \mathrm{~N}$ is the number of atoms of the corresponding chemical elements in the gross fuel formula. Based on the model in [17], a method for identifying the composition of the fuel is proposed. During the implementation of the method, the direct problem of determining the composition of the combustion products was solved for a given gross formula of gaseous fuel and fuel. It should be noted that the implementation of the solution of the direct problem no longer requires the use of fuel only in gaseous form. Various aggregate states may be considered.

The gross fuel formula in the form (2) is determined from the corresponding fuel and oxidizer formulas using the oxidizer excess coefficient $\alpha$ (including for the case $\alpha<1$ ). In other words, the model given in [16], when solving the direct problem, can be used to describe the combustion and gasification processes. For the case of gasification, there is a limitation. In accordance with the proposed model, the temperature and quantitative composition of the products of combustion (gasification) are determined on the basis of the equality of their enthalpy and the enthalpy of the initial fuel. This suggests that the energy released at the final stage of gasification is enough to self-sustain the process. Such a condition may be violated, for example, with increased humidity of the gasified substance. The possibility of solving the problem when supplying additional energy is discussed below.

The model described in [16], after correction, can also be used to solve the problem of slow pyrolysis. Consider the types of equations in the model [16].

The law of the masses. For the first eight substances from (1), using $\mathrm{CO}_{2}$ as an example, through partial pressures of the corresponding components, equations are written in the form:

$$
K_{\mathrm{CO}_{2}}(T)=\frac{P_{\mathrm{C}} P_{\mathrm{O}}^{2}}{P_{\mathrm{CO}_{2}}},
$$

were $K_{\mathrm{CO}_{2}}(T)$ is the constant of chemical equilibrium at the temperature of the combustion products $T$ for the reaction of the formation of $\mathrm{CO}_{2}$ from elements $\mathrm{C}$ and $\mathrm{O}$ (tabular value);

$P_{\mathrm{CO}_{2}}, P_{\mathrm{C}}, P_{\mathrm{O}}-$ partial pressures of the corresponding components in the mixture of combustion products.

Equation (3) is written using partial pressures instead of concentrations for the convenience of further transformations. For gas mixtures, it is possible to achieve a numerical equality of the concentrations of the components to their partial pressures. This is possible when considering a certain number of moles of fuel MT (2) instead of one mole. The $M_{F}$ value is an additional unknown quantity and is to be determined.

The law of conservation of matter. The equations are written for the last four elements from (1) taking into account $M_{F}$. As an example, the equation for (C) has the form: 


$$
M_{F} b C=P_{\mathrm{CO}}+P_{\mathrm{CO}_{2}}+P_{\mathrm{C}} .
$$

The left side of the equation displays the number of carbon atoms in the fuel (2). The right side of the equation displays the number of carbon atoms in the combustion products. As in (3), partial pressures act as concentrations.

Dalton's Law. It is written to close the system of equations, taking into account the additional value of $\mathrm{M}_{\mathrm{F}}$ :

$$
P_{\Sigma}=\sum_{i} P_{i},
$$

were $P_{\Sigma}$ - the pressure in the combustion chamber (furnace);

$P_{i}$ - partial pressures of the components of the products of combustion.

With this recording scheme, the partial pressures of the combustion products can differ by 15 to 20 orders of magnitude. To reduce the range of variation of values, all equations of the model are logrithmized. As a result, it is a system of nonlinear algebraic equations. In the linearization process, derivatives are determined not by the corresponding arguments, but by their logarithms:

$$
\frac{d \sum_{i}\left\{\ln \left[f\left(P_{i}\right)\right]\right\}}{d\left[\ln \left(P_{i}\right)\right]}=\frac{\sum_{i} d\left\{\ln \left[f\left(P_{i}\right)\right]\right\}}{d\left[\ln \left(P_{i}\right)\right]} .
$$

When solving the problems of pyrolysis, it becomes necessary to take into account the additional component of the mixture of reaction products - the carbon residue in the form of a condensed phase. Denote its concentration by $P_{\mathrm{U}}$. To close the system, let's write another equation of the form (3) for the carbonaceous residue formation reaction:

$$
K_{U}(T)=\frac{P_{\mathrm{C}}}{P_{\mathrm{U}}} .
$$

After taking of logarithm, equation (7) will look like:

$$
\ln \left(P_{\mathrm{C}}\right)-\ln \left(P_{\mathrm{U}}\right)-\ln \left[K_{\mathrm{U}}(T)\right]=0 .
$$

One of the features of the model is manifested in the linearization of equation (8). The PU concentration for a given temperature does not change. The derivative of the corresponding term in equation (8), in contrast to other equations of the form (3), is equal to zero. The linearized equation has the form:

$$
1 \Delta\left[\ln \left(P_{\mathrm{C}}\right)\right]=(-1)\left\{\ln \left(P_{\mathrm{C}}\right)-\ln \left(P_{\mathrm{U}}\right)-\ln \left[K_{\mathrm{U}}(T)\right]\right\}^{*} .
$$

In this expression, the sign $\left({ }^{*}\right)$ denotes the initial approximation and the corresponding initial approximations $P_{\mathrm{C}}$ and $P_{\mathrm{U}}$ or the values from the previous calculation step are used on the right side.

When writing down the law of conservation of matter, the $P_{\mathrm{U}}$ value is taken into account in the balance of the number of carbon atoms and equation (4) has the form:

$$
M_{F} b C=P_{\mathrm{CO}}+P_{\mathrm{CO}_{2}}+P_{\mathrm{U}}+P_{\mathrm{C}} .
$$
volume.

When writing the Dalton law (5), the $P_{\mathrm{U}}$ value is not taken into account due to the small specific

Calculations based on the proposed model are simpler for the case of pyrolysis compared with combustion and gasification. So, for the case of pyrolysis, the temperature of the reaction products is set and the iterative process of calculations is determined only by solving a nonlinear system of equations. When calculating the combustion and gasification processes, the temperature of the combustion products is sought within the external stage of the iterative process.

Thus, a single model is selected and adapted to solve the problems of combustion, gasification and slow pyrolysis with a known composition of the initial hydrocarbon substances. Variants of the model for calculating various processes are distinguished by the presence of a condensed phase of a carbonaceous substance. As part of the calculation of the combustion and gasification process, the 
temperature of the combustion products is determined. During pyrolysis, the temperature of the reaction products is set.

Examples of calculation of the processes of combustion and pyrolysis of hydrocarbon substances of known composition on the basis of a single model

In order to reduce cumbersomeness without changing the generality of presentation, model (1) - (5) is constructed for the process of combustion of hydrocarbon substances in air. To verify the operability of the model used in the study of combustion and gasification processes, the combustion of methane $\left(\mathrm{CH}_{4}\right)$ and ethyl alcohol (gross formula $\left.\mathrm{C}_{2} \mathrm{H}_{6} \mathrm{O}\right)$ was previously performed.

The calculations are performed for various values of the coefficient of excess oxidizer $\alpha$. At $\alpha=1$, the process is considered as burning (when $\alpha<1-$ as gasification). The results of calculations according to the proposed model and the data from [18] are compared when methane and ethyl alcohol were burned in air. The values of temperature $T(\mathrm{~K})$ and partial pressures $P_{i}$ (in bars) of the combustion products at a pressure in the combustion chamber (furnace) of 1 bar are given. The comparison is carried out for various values $\alpha$ by determining the relative error $\varepsilon$ of the calculation of partial pressures relative to the pressure in the combustion chamber. The minimum reduced values $\alpha$ is due to the availability of data in [18]. Based on the model used, calculations can be performed for any value of $\alpha$.

The obtained results show good agreement between the calculation results for the proposed model and those given in [18]. The relative errors in determining the partial pressures during methane combustion do not exceed $1 \%$, and for ethanol $-1.4 \%$ and do not exceed the values allowed for engineering calculations $(<5 \%)$. Part of the resulting error may be due to the use of approximate air composition in the calculations.

To assess the reliability of the model used in solving the problem of thermochemical transformations of solids with a variety of experimental works, it was not possible to find structured data. In their quality, the experimental values of the ranges of changes in the concentrations of the main groups of transformation products for the initial wood raw material from pine were used. Such data are available in most available literary sources of various years. This determines their choice.

The composition of the gross formula and the enthalpy of the starting material (pine wood) used in the calculations were determined on the basis of indirect data. The values of these data in various sources are close, but, nevertheless, are not the same and are given in a certain range. For this reason, a specific source of their values is not indicated. It is accepted that pine wood includes: $\mathrm{C}-49 . .50 \%$; $\mathrm{O}-42 \ldots 44 \% ; \mathrm{H}-6 . . .7 \%$. In addition, the composition of wood includes $\sim 0.1 \ldots 1 \% \mathrm{~N}$ and up to $1 \%$ of mineral components (ash). These substances are not taken into account due to the smallness of their concentrations in the evaluative nature of the calculations. As a result, $\mathrm{CH}_{1.44} \mathrm{O}_{0.64}$ is adopted as the gross formula of the feedstock. The heat production of absolutely dry pine wood in a number of sources is indicated at the level of $2100{ }^{\circ} \mathrm{C}(2370 \mathrm{~K})$, which makes it possible to estimate the enthalpy of the feedstock with a value of $-68.24 \mathrm{~kJ} / \mathrm{mol}(-2880 \mathrm{~kJ} / \mathrm{kg})$.

The combustion process with a stoichiometric ratio of fuel and oxidizer in a simplified form is considered as a process of complete oxidation of combustible substances. For pine wood, it looks like this:

$$
\mathrm{CH}_{1.44} \mathrm{O}_{0.64}+\underbrace{1.04 \mathrm{O}_{2}+3.91 \mathrm{~N}_{2}}_{\text {air }}=\mathrm{CO}_{2}+0.72 \mathrm{H}_{2} \mathrm{O}+3.91 \mathrm{~N}_{2}
$$

The calculation results of this process based on the proposed model are displayed (highlighted) in the corresponding row in the Table 1 . As before, the pressure of the combustion products in the combustion chamber (furnace) is assumed to be $P_{\Sigma}=1$ bar.

The list of combustion products displayed in the Table 1 is wider than the similar list in (11). Nevertheless, these data can be compared if to find the number of products containing $\mathrm{H}$ and $\mathrm{N}$ per 1 mole of substances containing C:

$$
\frac{P_{\mathrm{H}_{2} \mathrm{O}}+P_{\mathrm{OH}}+P_{\mathrm{H}_{2}}}{P_{\mathrm{CO}}+P_{\mathrm{CO}_{2}}}=\frac{0.121+0.004+0.003}{0.019+0.156}=0.731 \text {, }
$$




$$
\frac{P_{\mathrm{N}_{2}}+P_{\mathrm{NO}}}{P_{\mathrm{CO}}+P_{\mathrm{CO}_{2}}}=\frac{0.684+0.003}{0.019+0.156}=3.926
$$

Table 1

Temperature and concentration (partial pressures, volume fractions) of pine wood combustion products at various values of oxidizer excess coefficient $\alpha$

\begin{tabular}{c|c|c|c|c|c|c|c|c|c}
\hline \multirow{2}{*}{$\alpha$} & \multirow{2}{*}{$T, \mathrm{~K}$} & \multicolumn{8}{|c}{ Concentrations (partial pressures, bar) of reaction products } \\
\cline { 3 - 11 } & & $\mathrm{CO}$ & $\mathrm{CO}_{2}$ & $\mathrm{H}_{2} \mathrm{O}$ & $\mathrm{OH}$ & $\mathrm{H}_{2}$ & $\mathrm{~N}_{2}$ & $\mathrm{O}_{2}$ & NO \\
\hline 2.5 & 1409 & 0 & 0.077 & 0.055 & 0 & 0 & 0.749 & 0.119 & 0 \\
\hline 2.2 & 1530 & 0 & 0.086 & 0.062 & 0 & 0 & 0.743 & 0.107 & 0 \\
\hline 1.9 & 1681 & 0 & 0.099 & 0.071 & 0 & 0 & 0.736 & 0.092 & 0.0017 \\
\hline 1.6 & 1870 & 0.0001 & 0.116 & 0.083 & 0 & 0 & 0.723 & 0.071 & 0.0028 \\
\hline 1.3 & 2119 & 0.0015 & 0.139 & 0.100 & 0.002 & 0.0003 & 0.711 & 0.042 & 0.0043 \\
\hline 1 & 2356 & 0.019 & 0.156 & 0.121 & 0.004 & 0.003 & 0.684 & 0.008 & 0.003 \\
\hline 0.9 & 2371 & 0.040 & 0.150 & 0.128 & 0.003 & 0.007 & 0.667 & 0.002 & 0.0016 \\
\hline 0.8 & 2316 & 0.072 & 0.134 & 0.132 & 0.0015 & 0.015 & 0.644 & 0 & 0 \\
\hline 0.6 & 2071 & 0.153 & 0.093 & 0.125 & 0 & 0.052 & 0.577 & 0 & 0 \\
\hline 0.4 & 1661 & 0.246 & 0.058 & 0.085 & 0 & 0.134 & 0.476 & 0 & 0 \\
\hline 0.3 & 1348 & 0.303 & 0.043 & 0.048 & 0 & 0.201 & 0.406 & 0 & 0 \\
\hline
\end{tabular}

The deviation of the results of (12), (13) from the values of (11) (the number of moles of $\mathrm{H}_{2} \mathrm{O}$ and $\mathrm{N}_{2}$ ) does not exceed $1.5 \%$. At the same time they are more informative. The calculation results (Table 1) reflect the main features of the combustion and gasification processes. Thus, the temperature of the reaction products is shown to be higher for $\alpha=0.9$ compared to $\alpha=1.0$. This is due to the large influence of an increase in ballast in the form of $\mathrm{N}_{2}$ compared to an increase in the energy received in the form of heat. This gas must be heated, but it does not take part in the reaction. The calculation results adequately reflect the change in the ratio of $\mathrm{CO}, \mathrm{CO}_{2}$, and $\mathrm{H}_{2} \mathrm{O}$ as $\alpha$ change, during the transition from combustion to gasification. The increase in the number of nitrogen oxides with increasing free $\mathrm{O}_{2}$ with increasing $\alpha$ is shown. Starting from a certain value of $\alpha$, a decrease in the amount of $\mathrm{NO}$ occurs despite a continuing increase in $\mathrm{O}_{2}$ in the reaction products. This is due to a decrease in their temperature.

Further, in comparison with the Table 1, a decrease in the value of $\alpha$ leads to the impossibility of organizing the combustion process (gasification). At $\alpha=0$ and heating of the hydrocarbon material, its dry distillation occurs (slow pyrolysis). The calculation results for the parameters of this process based on the proposed model are given in Table 2. The composition of the reaction products takes into account an additional component - carbonaceous residue (U).

It is noted the formation of condensable hydrocarbon substances - slurry (acetic acid, resins and others) in experimental studies of low-temperature $\left(350 \ldots 4500^{\circ} \mathrm{C}\right)$ slow pyrolysis of wood.

This is the result of relatively rapid removal of decomposition products from the heating zone. High molecular weight volatile hydrocarbon substances resistant to thermal degradation do not have time to decompose into simple ones. This effect is manifested more clearly in the processes of rapid pyrolysis. With an increase in the temperature of slow pyrolysis or an increase in the residence time of the reaction products in the heating zone, the amount of condensing substances decreases, until they disappear completely. Table 2 presents the results of calculating the parameters of just such a process. For this reason, the list of reaction products does not contain hydrocarbon substances other than methane. Consideration on the basis of the proposed model of fast pyrolysis processes with the formation of a large number of condensing substances will be the subject of additional research. In the literature for slow pyrolysis, the composition of the reaction products is indicated in mass fractions (mi). The same values are used in the Table 2 to display the results of calculations.

To assess the adequacy of the results let's use the basic characteristics of slow and high temperature pyrolysis of Table 3 given in (13). 
Slow pyrolysis (Table 3) corresponds to the calculation results (Table 2) at a temperature of $T=700 \mathrm{~K}$. The relative error of the calculated coal fraction of $34 \%$ differs from the experimental data by no more than $3 \%$. The error in calculating the proportion of water is even smaller and amounts to $\sim 1.5 \%$. For high-temperature pyrolysis, the difference between the calculated values is greater, but also does not contradict the nature of the data. It should be noted that the experimental data are given for a certain range of conditions. The calculated values are determined for a fixed temperature value.

Table 2

Mass fractions (mi) of wood pyrolysis products at various temperatures (T)

\begin{tabular}{c|c|c|c|c|c|c}
\hline$T, \mathrm{~K}$ & $\mathrm{CO}$ & $\mathrm{CO}_{2}$ & $\mathrm{H}_{2} \mathrm{O}$ & $\mathrm{CH}_{4}$ & $\mathrm{H}_{2}$ & $\mathrm{U}$ \\
\hline 700 & 0.003 & 0.288 & 0.246 & 0.112 & 0.005 & 0.34 \\
\hline 900 & 0.102 & 0.294 & 0.178 & 0.05 & 0.028 & 0.343 \\
\hline 1100 & 0.490 & 0.125 & 0.067 & 0.06 & 0.051 & 0.255 \\
\hline 1300 & 0.707 & 0.019 & 0.014 & 0.001 & 0.059 & 0.195 \\
\hline 1500 & 0.744 & 0.003 & 0.003 & 0 & 0.060 & 0.184 \\
\hline
\end{tabular}

Table 3

Characteristics of the types of pyrolysis

\begin{tabular}{c|c|c|c|c}
\hline Process & Conditions & \multicolumn{3}{|c}{ Products, wt. \% } \\
\cline { 3 - 5 } & Distillate & Coal & Gas \\
\hline $\begin{array}{c}\text { Slow } \\
\text { pyrolysis }\end{array}$ & Low temperature $\left(350 \ldots 450{ }^{\circ} \mathrm{C}\right)$, long process & 30 & 35 & 35 \\
\hline $\begin{array}{c}\text { High temperature } \\
\text { pyrolysis }\end{array}$ & High temperature $\left(>600{ }^{\circ} \mathrm{C}\right)$ & $\begin{array}{c}\text { (water up } \\
\text { to } 75 \%)\end{array}$ & 10 & 85 \\
\hline
\end{tabular}

Thus, the results of calculations performed using the proposed unified model adequately reflect the parameters of various processes of thermochemical conversion of hydrocarbon substances: combustion, gasification, and slow pyrolysis. The relative error of the calculations does not go beyond the permissible values for engineering calculations $(<5 \%)$.

A method for determining the composition of the initial hydrocarbon substance in various states of aggregation in real time

All the above calculation results are obtained under the condition of a known composition of the starting materials. When to change the type, quality of the feedstock, this condition is violated and the results lose relevance. Without identifying the composition of the starting materials, it is impossible to organize a controlled process of their thermochemical processing.

The calculations in the study of all the processes considered are based on the use of the gross formula of the starting material. Another feature is the identity of the gross formulas of the starting material and the sum of the reaction products. These properties are the basis of the method for determining the composition of hydrocarbon substances in thermochemical processing.

In [17], a method is proposed for determining the composition (gross formula) of combustible gas during its combustion. The method is based on solving the inverse problem. Instead of the calculated temperature value (as a function), it is used as a known value (argument). For this, the temperature in the combustion chamber is measured. As a result, it becomes possible, on the basis of the existing system of equations, to determine one of the quantities of atoms in the gross formula (2). By varying the combustible gas-air ratio and measuring the corresponding temperatures, it is possible to formulate a system of equations for determining all values of the number of atoms in formula (2). Because the composition of the combustible gas at the time of determining its composition is unknown, then instead of the values of $\alpha$ and the molar stoichiometric coefficient of the component ratio $\chi_{0}$ required for the calculations, the measured value of the ratio of the volumetric flow rates of gaseous fuel and oxidizer is also used. At relatively low pressures, all gases are close to ideal in properties. In this 
case, the molar volumes of any gases are the same and equal to $\sim 22.4 \mathrm{l} / \mathrm{mol}$. As a result, it is possible to introduce the replacement into the system of equations:

$$
\alpha \chi_{0}=\frac{\dot{V}_{o x}}{\dot{V}_{\text {comb }}} .
$$

A feature in the organization of such a process for determining the composition of the fuel is the need to ensure the isoenthalpy of the combustion process. It can be provided in a combustion chamber similar to a rocket engine with a regenerative cooling system with one or both components.

The method is based on the model considered in this article. But a mixture of gases, albeit of unknown composition, which can burn, can be obtained from liquid and solid hydrocarbon substances in the process of gasification with small $\alpha$ values. Based on these comments, the composition determination process is structured as follows:

- in a separate device of a small size, an uncontrolled process of gasification of a substance is carried out, the composition of which must be determined. In this case, the flow rate of air supplied to gasification is taken into account;

- in accordance with the method proposed in [17], the gas obtained in the previous step is burned in a special device and its composition is determined (gross formula);

- based on this formula and excluding the air spent on gasification in the first stage, the gross formula of the starting material is determined.

Thus, on the basis of the proposed algorithm, a closed-loop process can be carried out to quickly determine the changing composition of a mixture of hydrocarbon substances of an arbitrary phase composition and their controlled thermochemical processing.

\section{Discussion of the results of solving the problem of combustion, gasification and slow pyroly- sis of hydrocarbon substances}

In existing methods, the initial data for the calculation are substances or mixtures of substances of known composition. Real mixtures may consist of a large number of them. So the standard for chromatography of natural gas involves determining the percentage of more than 30 individual substances included in it. When used for thermochemical treatment of household, agricultural and other wastes, the same problems exist in determining their composition. The complexity of describing the composition of substances and their mixtures is significantly reduced when using their gross formulas (2). Using only four chemical elements $(\mathrm{C}),(\mathrm{H}),(\mathrm{O})$ and $(\mathrm{N})$ allows to describe the composition of most organic substances. So taking into account another element (S) allows to describe the composition of the above noted natural gas. The simplicity of the gross formulas with a known composition of the starting materials allows their use for calculating various processes of thermochemical transformations ([19], [20], Table 1). Such universalism at the initial stage served as the basis for expanding the applicability of the gross formula for calculating the region of slow pyrolysis with a known composition of the feedstock (Table 2).

Adequate results in the calculation of combustion and gasification processes are obtained due to the high temperatures of the processes. The presence of condensable substances during pyrolysis is a consequence of low temperatures and the relatively rapid removal of products from the reaction zone (heating zone). With increasing temperature, their number decreases, which is confirmed by the data in Table 2.

Pyrolysis, in contrast to combustion and gasification, is characterized by the production of condensed (carbonaceous residue) and condensed substances (distillate). The carbonaceous residue is the product of the final decomposition of hydrocarbon substances. Therefore, the model under consideration well describes the process of its formation. Condensable substances in the reaction zone are in a gaseous state, but do not reach the final stage of decomposition. To describe the process of their formation, the model used in the article should be finalized, which is the subject of further research.

The noted simplification of calculations using the gross formula also underlies the method for determining the composition of gaseous organic substances and mixtures during their combustion [16]. Such universalism makes it possible to propose a method for determining the composition of various organic substances by generally uncontrolled gasification of a small number of them. Such a process 
of gasification and determination of the composition of the gross formula can occur in real time in parallel with the main process of thermal processing of substances and ensure its controllability and controllability.

The proposed unified model for identifying the composition of products of combustion, gasification, and slow pyrolysis can serve as a basis for calculating the necessary parameters and controlling the corresponding processes based on them. This does not exclude the need for engineering, metrological support of the relevant processes and requires additional research.

\section{Conclusions}

1. A single model is selected and adapted to solve the problems of combustion, gasification and slow pyrolysis with a known composition of the initial hydrocarbon substances. The model uses the partial pressures of the reaction products as determined quantities. This approach implies their gaseous state. A feature of the model under consideration is the possibility of taking into account the condensed phase in the calculations. In this case, it is a carbonaceous residue during pyrolysis;

2. The results of calculations based on a single model of the compositions of the products of slow pyrolysis are presented. Their relative error does not exceed the permissible value for engineering calculations $(<5 \%)$. This corresponds to the accuracy of the calculations of the combustion and gasification processes for which the adapted model is originally developed;

3. A method is developed for determining in real time the composition of the hydrocarbon component of combustible substances in various aggregate states according to the single proposed model, which represents a further development of the model proposed in [17].

\section{Література}

1. New Satellite Data Reveals Progress: Global Gas Flaring Declined in 2017. Press release, July 17, 2018. URL: https://www.worldbank.org/en/news/press-release/2018/07/17/new-satellite-data-reveals-progress-globalgas-flaring-declined-in-2017.

2. Eman A.E. Gas Flaring in Industry: an Overview. Petroleum \& Coal. 2015. 57(5). 532-555. URL: www.vurup.sk/petroleum-coal.

3. IPCC, 2014: Climate Change 2014: Synthesis Report. Contribution of Working Groups I, II and III to the Fifth Assessment Report of the Intergovernmental Panel on Climate Change. URL: https://www.ipcc.ch/site/assets/uploads/2018/05/SYR_AR5_FINAL_full_wcover.pdf.

4. Brown R. C. Thermochemical Processing of Biomass: Conversion into Fuels, Chemicals and Power. Wiley, 2019. 408 p. ISBN: 978-1-119-41757-6.

5. Perrot J.-F., Subiantoro A. Municipal Waste Management Strategy Review and Waste-to-Energy Potentials in New Zealand. Sustainability. 2018. 10(9). 3114. DOI: https://doi.org/10.3390/su10093114.

6. Astrup T.F., Tonini D., Turconi R., Boldrin A. Life cycle assessment of thermal Waste-to-Energy technologies: Review and recommendations. Waste Management. 2015. Vol. 37. 2015. P. 104-115. DOI: https://doi.org/10.1016/j.wasman.2014.06.011.

7. Bosmans A., Vanderreydt I., Geysen D., Helsen L. The crucial role of Waste-to-Energy technologies in enhanced landfill mining: a technology review. Journal of Cleaner Production. 2013. Vol. 55. P. 10-23. DOI: https://doi.org/10.1016/j.jclepro.2012.05.032.

8. Leibbrandt N.H., Aboyade A.O., Knoetze J.H., Görgens J.F. Process Efficiency of Biofuel Production Via Gasification and Fischer-Tropsch Synthesis. Fuel. 2013. Vol. 109. 2013. P. 484-492. DOI: doi.org/10.1016/j.fuel.2013.03.013.

9. An overview of advances in biomass gasification / V.S. Sikarwar, M. Zhao, P. Clough et al. Energy Environ. Sci., 2016, 9, 2939-2977. DOI: 10.1039/C6EE00935B.

10. Samiran N.A., Jaafar M.N.M., Ja'afar M., Chong C.T. Review of Biomass Gasification Technology to produce Syngas. American-Eurasian Journal of Sustainable Agriculture. 8(7), March 2014. URL: https://www.researchgate.net/publication/278849675.

11. Kwiatkowski K., Dudyński M., Bajer K. Combustion of Low-Calorific Waste Biomass Syngas. Flow, Turbulence and Combustion. 2013. Vol. 91, Issue 4. P. 749-772. DOI: https://doi.org/10.1007/s10494013-9473-9. 
12. Potential of Pyrolysis Processes in the Waste Management Sector / D.Czajczyńska, L.Anguilano, H.Ghazal, R.Krzyżyńska, A.J.Reynolds, N.Spencer, H.Jouharaa / Thermal Science and Engineering Progress. 2017. Vol. 3. P. 171-197. DOI: doi.org/10.1016/j.tsep.2017.06.003.

13. A review on pyrolysis of plastic wastes / S.D.A. Sharuddin, F. Abnisa, Wan M.A. Wan Daud, M.K. Aroua. Energy Conversion and Management. 2016. 115. 308-326. DOI: https://doi.org/ 10.1016/j.enconman.2016.02.037.

14. An open-source biomass pyrolysis reactor / D. Woolf, J. Lehmann, S. Joseph and others. Biofuels, Bioproducts and Biorefining. 2017. Vol. 11, Is. 6. DOI: https://doi.org/10.1002/bbb.1814.

15. Huang Y.-F., Chiueh P.-T., Lo S.-L. A review on microwave pyrolysis of lignocellulosic biomass. Sustainable Environment Research. 2016. Vol. 26, Is. 3. P. 103-109. DOI: https://doi.org/ 10.1016/j.serj.2016.04.012.

16. Максимов М.В., Брунеткин А.И., Бондаренко А.В. Модель и метод определения условной формулы углеводородного топлива при сжигании. Східно-європейський журнал передових технологій. 2013. №6/8 (66). С. 20-27.

17. Определение состава сжигаемого газа методом ограничений как задачи интерпретации модели / А. И. Брунеткин, В. О. Давыдов, А. В. Бутенко, А. П. Лысюк, А. В. Бондаренко. Східноєвропейський журнал передових технологій. 2019. №3/6 (99). С. 22-30. DOI: 10.15587/17294061.2019.169219.

18. Термодинамические и теплофизические свойства продуктов сгорания: справочник: в 6т. / под науч. ред. акад. В.П. Глушко. Москва: ВИНИТИ; Топлива на основе кислорода и воздуха. 1973. T. $3.624 \mathrm{c}$.

19. Брунеткин А.И., Максимов М.В. Метод определения состава горючих газов при их сжигании. Науковий вісник НГУ. 2015. №5. С. 83-90. URL: http://nbuv.gov.ua/UJRN/Nvngu_2015_5_16.

20. Максимов М.В., Брунеткин А.И., Максименко А.А., Лысюк О.В. Математическая модель определения состава смеси углеводородных кислородосодержащих газов сжигаемого топлива. Вчені записки таврійського національного університету ім. В.І. Вернадського, Серія Технічні науки. 2018. T. 29(68), №1, C. 77-84. URL: http://nbuv.gov.ua/UJRN/sntuts_2018_29_1\%282\%29_17.

\section{References}

1. New Satellite Data Reveals Progress: Global Gas Flaring Declined in 2017. Press release, July 17, 2018. Retrieved from: https:/www.worldbank.org/en/news/press-release/2018/07/17/new-satellite-datareveals-progress-global-gas-flaring-declined-in-2017.

2. Eman, A.E. (2015). Gas Flaring in Industry: an Overview. Petroleum \& Coal 57(5), 532-555. Retrieved from: www.vurup.sk/petroleum-coal.

3. IPCC, 2014: (2014). Climate Change 2014: Synthesis Report. Contribution of Working Groups I, II and III to the Fifth Assessment Report of the Intergovernmental Panel on Climate. Retrieved from: https://www.ipcc.ch/site/assets/uploads/2018/05/SYR_AR5_FINAL_full_wcover.pdf.

4. Brown, R. C. (2019). Thermochemical Processing of Biomass: Conversion into Fuels, Chemicals and Power. Wiley. ISBN: 978-1-119-41757-6.

5. Perrot, J.-F., \& Subiantoro, A. (2018). Municipal Waste Management Strategy Review and Waste-toEnergy Potentials in New Zealand. Sustainability, 10(9), 3114. DOI: https://doi.org/ 10.3390/su10093114.

6. Astrup, T.F., Tonini, D., Turconi, R., \& Boldrin, A. (2015). Life cycle assessment of thermal Waste-toEnergy technologies: Review and recommendations. Waste Management, 37, March 2015, 104-115. DOI: https://doi.org/10.1016/j.wasman.2014.06.011.

7. Bosmans A., Vanderreydt I., Geysen D., \& Helsen L. (2013). The crucial role of Waste-to-Energy technologies in enhanced landfill mining: a technology review. Journal of Cleaner Production, 55, 10-23. DOI: https://doi.org/10.1016/j.jclepro.2012.05.032.

8. Leibbrandt, N.H., Aboyade, A.O., Knoetze, J.H., \& Görgens, J.F. (2013). Process Efficiency of Biofuel Production Via Gasification and Fischer-Tropsch Synthesis. Fuel, 109, 484-492. DOI: doi.org/10.1016/j.fuel.2013.03.013.

9. Sikarwar, V.S. Zhao, M., Clough, P. \& et al. (2016). An overview of advances in biomass gasification. Energy Environ. Sci., 9, 2939-2977. DOI: 10.1039/C6EE00935B. 
10. Samiran, N.A., Jaafar, M.N.M., Ja’afar, M., \& Chong, C.T. (2014). Review of Biomass Gasification Technology to produce Syngas. American-Eurasian Journal of Sustainable Agriculture 8(7). Retrieved from: https://www.researchgate.net/publication/278849675.

11. Kwiatkowski, K., Dudyński, M., \& Bajer, K. (2013). Combustion of Low-Calorific Waste Biomass Syngas. Flow, Turbulence and Combustion, 91, 4, 749-772. DOI: https://doi.org/10.1007/s10494-0139473-9.

12. Czajczyńska, D., Anguilano, L., Ghazal, H., Krzyżyńska, R., Reynolds, A.J., Spencer, N., \& Jouharaa, H. (2017). Potential of Pyrolysis Processes in the Waste Management Sector. Thermal Science and Engineering Progress, 3, 171-197. DOI: doi.org/10.1016/j.tsep.2017.06.003.

13. Sharuddin, S.D.A., Abnisa, F., Wan Daud Wan, M.A., \& Aroua, M.K. (2016). A review on pyrolysis of plastic wastes. Energy Conversion and Management, 115, 308-326. DOI: https://doi.org/ 10.1016/j.enconman.2016.02.037.

14. Woolf, D., Lehmann, J., Joseph, S. \& et al. (2017). An open-source biomass pyrolysis reactor. Biofuels, Bioproducts and Biorefining, 11, 6. DOI: https://doi.org/10.1002/bbb.1814.

15. Huang, Y.-F., Chiueh, P.-T. , \& Lo, S.-L. (2016). A review on microwave pyrolysis of lignocellulosic biomass. Sustainable Environment Research, 26, 3, 103-109. DOI: https://doi.org/ 10.1016/j.serj.2016.04.012.

16. Maksymov, M.V., Brunetkin, A.I., \& Bondarenko, A.V. (2013). Model and Method for Determining the Conditional Formula for Hydrocarbon Fuel During Combustion. Eastern-European Journal of Enterprise Technologics, 6/8 (66), 20-27.

17. Brunetkin, O., Davydov, V., Butenko, O., Lysiuk, G., \& Bondarenko, A. (2019). Determination of the Composition of the Combined Gas by the Method of Limitations as the Tasks of the Interpretation of the Model. Eastern-European Journal of Enterprise Technologics, 3/6 (99), 22-30. DOI: 10.15587/1729-4061.2019.169219.

18. Glushko, V.P., (Ed). (1971). Thermodynamic and Thermophysical Properties of Combustion Products: a Handbook (Vols 1-6). Moscow, Soviet Union : All-Union Institute of Scientific and Technical Information, vol. 3 .

19. Brunetkin, A.I., \& Maksymov, M.V. (2015). Method for Determining the Composition of Combustion Gases when Burned. Scientific Journal Natsionalnho Mining University, 5, 83-90. URL: http://nbuv.gov.ua/UJRN/Nvngu_2015_5_16.

20. Maksimov, M.V., Brunetkin, O.I., Maksimenko, A.A., \& Lysyuk, O.V. (2018). A Mathematical Model for Determining the Composition of a Mixture of Hydrocarbon Oxygen-Containing Gases of Combusted Fuel. All the notes of the Tauride National University B.I. Vernadskogo, Technology. 29 (68), 1, 7784. URL: http://nbuv.gov.ua/UJRN/sntuts_2018_29_1\%282\%29_1.

Брунеткін Олександр Іванович; Brunetkin Olexander, ORCID: http:// orcid.org /0000-0002-6701-8737

Максимов Максим Максимович; Maksymov Maksym 